Jurnal Agribis

Vol. 7, No.1, Tahun 2021

\title{
ANALISIS USAHA PEMBENIHAN IKAN LELE SANGKURIANG (Clarias gabrie pinus) Studi Kasus Di BBI Bolorejo Kecamatan Kauman Kabupaten Tulungagung
}

\author{
Yuniar Hajar Prasekti ${ }^{* 1}$ dan Irfan Yahya Hadianto ${ }^{2}$ \\ ${ }^{1}$ Program Studi Agribisnis, Fakultas Pertanian, Universitas Tulungagung \\ ${ }^{2}$ Program Studi Agribisnis, Fakultas Pertanian, Universitas Tulungagung \\ 1 \\ E-mail:yuniarhajarprasekti@unita.ac.id
}

\begin{abstract}
ABSTRAK
Tujuan penelitian terkait dengan usaha pembenihan ikan lele sangkuriang untuk mengetahui pendapatan petani pembenihan ikan lele di Kabupaten Tulungagung. Metode pengambilan sampel dilakukan secara sensus, selain itu untuk analisis data menggunakan kualitatif dan kuantitatif. Pelaksaan penelitian tersebut dilaksanakan tanggal 2 Februari - 28 April 2020. Hasil penelitian menunjukkan Balai Benih Ikan Bolorejo melakukan sistem pembenihan ikan lele sangkuriang menggunakan dua sistem yakni alami dan buatan. Pendapatan yang paling besar terdapat pada sistem buatan sebesar Rp 3.000.000/siklus pemijahan dan pendapatan Rp 2.000.000/siklus pemijahan untuk sistem alami. Sedangkan untuk Benefit Cost Ratio pada sistem buatan sebesar 1,4 dan 1,1 untuk sistem alami.
\end{abstract}

Kata Kunci: analisis usaha, pembenihan, ikan lele sangkuriang

\begin{abstract}
The research objective is related the catfish sangkuriang to determine the income of catfish farmers in Tulungagung Regency. The sampling method was carried out by census, in addition to data analysis using qualitative and quantitative. This research was on 2 February - 28 April 2020. The results showed that the Bolorejo Fish Seed Center carried out a catfish sangkuriang system using a natural system and an artificial system. The highest income is found in artificial systems, amounting to Rp. 3,000,000/spawning cycle and Rp. 2,000,000/spawning cycle for natural systems. Meanwhile, the Benefit Cost Ratio for artificial systems is 1.4 and 1.1 for natural systems.
\end{abstract}

Keywords: analysis business, hatchery, catfish sangkuriang 


\section{PENDAHULUAN}

Komoditas perikanan yang banyak dibudidayakan masyarakat Indonesia salah satunya Ikan lele. Selain itu memiliki banyak tergantung gizi dan nilai akan ikan lele murah sehingga di gemari oleh masyarakat. Namun besarnya kebutuhan ikan lele belum diimbangi dengan pasokan pakan. Selama ini proses budidaya ikan lele tergantung kebutuhan pakan yang akan berpengaruh pada biaya produksi. Hal ini karena kebutuhan pakan 60\%-70\% akan mempengaruhi kelangsungan usaha budidaya ikan lele (Anggriani et al., 2012).

Kebutuhan akan pakan ikan lele sangat penting, maka faktor pendorong akan pembuatan makanan ternak secara buatan. Pakan buatan terdiri dari kombinasi bahan-bahan yang mempunyai kandungan nutrisi tinggi. Kandungan gizi harus memenuhi protein sebesar $28 \%$, karbohidrat dan lemak masing-masing sebesar 4 persen serta daya sebanyak $2040 \mathrm{kkal}$ setiap $1 \mathrm{~kg}$ pakan (Sundary, 2014). Perihal yang berbeda terkait kwalitas tiap sifat bahan baku serta banyaknya proses bahan baku pada makanan hewan akan berpengaruh terhadap peningkatan jumlah lele. Selain itu kekeliruan dalam menentukan bahan baku yang dipergunakan memiliki dampak minimal kandungan nutrisi serta maksimalnya biaya pakan buatan yang dihasilkan (Wardhani et, al. 2011).

Aturan pemberian pakan ternak lele Sangkuriang sebanyak 2-3 kali sehari dengan banyaknya pakan ternak yang diberikan $2 \%$ dari keseluruhan bobot pakan ternak. Oleh sebab tersebut memerlukan upaya susunan pakan ternak untuk mengadakan pemecahan permasalahan paling baik serta kwalitas dengan biaya minimal (Sundary, 2014). Namun pakan ternak biaya operasional adalah biaya tenaga kerja, dimana faktor biaya tenaga kerja salah satu faktor tetap dengan maksud pembiayaan produksi besarnya tidak bergantung kepada tingkat produksi. Sedangkan faktor pembiayaan pakan ternak menjadi faktor pembiayaan produksi tidak tetap yang berarti jumlahnya bergantung kepada tingkat produksi dengan memaksimalkan pendapatan bersih penjualan lele dengan upaya memproduksi pakan ternak. Demikian tujuan pada penelitian ini terkait dengan pendapatan pembenihan ikan lele sangkuriang dengan pemijahan alami dan buatan. 


\section{METODE PENELITIAN}

Penelitian dilakukan di Balai Benih Ikan (BBI) pada tanggal 2 Februari - 28 April 2020 berlokasi di Desa Bolorejo Kecamatan kauman Kabupaten Tulungagung. Sedangkan pengambilan sampel menggunakan sistem sensus tanpa melihat tahapan yang ada pada populasi. Penggunaan akan pengumpulan data yakni wawancara, observasi, serta kepustakaan. Penggunaan analisis data penelitian salah satunya Laba/Rugi, digunakan untuk melihat keuntungan/kerugian yang diterima masingmasing produsen dan B/C Ratio dipergunakan untuk investasi yang waktu maupun siklus kegiatan usaha relative sangat pendek di bawah 1 tahun (Sumardika, 2013).

\section{HASIL DAN PEMBAHASAN}

\section{Perhitungan Biaya Pembibitan Ikan Lele Sangkuriang dengan cara Alami}

Pembibitan ikan lele Sangkuriang salah satu bagian penentuan keadaan berhasil mengusahakan pembudidayaan di bidang perikanan. Sebab itu pembibitan dipilih sebagai perolehan mengenai keseluruhan yang tidak dapat dipisahkan dari pembudidayaan lele Sangkuriang. Sedangkan untuk memperhitungkan pembiayaan hendak memusatkan perhatian kepada aktivitas pembibitan dengan penggunaan bermacam-macam pendugaan yang dapat diterima sebagai dasar.

Tabel 1. Kegiatan pembenihan ikan lele selama 1 siklus dengan sistem alami

\begin{tabular}{|l|l|l|l|}
\hline No & \multicolumn{1}{|c|}{ Kegiatan } & \multicolumn{1}{|c|}{ Hari ke- } & Durasi (hari) \\
\hline 1 & Pembersihan tempat pengembangbiakan & 1 & \\
\hline 2 & Pengeringan tempat pengembangbiakan & 1 & \\
\hline 3 & mengisikan air & 2 & \\
\hline 4 & Penyediaan ijuk pengembangbiakan & 2 & \\
\hline 5 & Pengambilan \& penebaran induk & 2 & \\
\hline 6 & Pengembangbiakan induk & 3 & \\
\hline 7 & Pengembalian induk & 3 & 1 \\
\hline 8 & Inkubasi telur & $3-4$ & 3 \\
\hline 9 & Cadangan makanan ikan & $4-6$ & 4 \\
\hline 10 & Pakan kutu air & $7-10$ & 5 \\
\hline 11 & Pakan cacing sutra & $11-15$ & 15 \\
\hline 12 & Pakan pellet halus & $16-30$ & \\
\hline 13 & Pemanenan benih & 30 & \\
\hline
\end{tabular}

Tabel 2. Biaya operasional dalam 1 siklus pembibitan ikan lele dengan sistem alami

\begin{tabular}{|l|l|l|r|r|}
\hline No & Kebutuhan & Jumlah & Biaya Satuan (Rp) & Biaya Total (Rp) \\
\hline & Biaya Tidak Tetap & & & \\
\hline 1 & ljuk pemijahan & 4 bks & 5000 & 20.000 \\
\hline
\end{tabular}




\begin{tabular}{|l|l|l|r|r|}
\hline No & Kebutuhan & Jumlah & Biaya Satuan (Rp) & Biaya Total (Rp) \\
\hline 2 & Raparasi kolam bocor & 4 kolam & 12.000 & 48.000 \\
\hline 3 & Kutu air & 12 kaleng & 10.000 & 120.000 \\
\hline 4 & Cacing sutera & 50 takar & 10.000 & 500.000 \\
\hline 5 & Biaya listrik & 1 siklus & 100.000 & 100.000 \\
\hline 6 & Transportasi & 2 liter & 10.000 & 20.000 \\
\hline 7 & Spon kawat & 4 buah & 2500 & 10.000 \\
\hline 8 & Bak sortir & 2 buah & 30.000 & 60.000 \\
\hline 9 & Pellet halus & 1 sak & 180.000 & 180.000 \\
\hline 10 & Lain-lain & & & 20.000 \\
\hline & Total & & & 1.078 .000 \\
\hline & Biaya Tetap & & & 65.000 \\
\hline 1 & Selang & 5 meter & 13.000 & 12.000 \\
\hline 2 & Thermometer & 1 unit & 12.000 & 150.000 \\
\hline 3 & Airrator & 1 unit & 150.000 & 450.000 \\
\hline 4 & Pompa air & 1 paket & 450.000 & 677.000 \\
\hline & Total & & & \\
\hline
\end{tabular}

Sumber data: Data Primer, 2020

Perhitungan keseluruhan pembiayaan pengusaha budi daya lele Sangkuriang banyak tanda yang diamati, salah satunya tanda aktivitas perawatan induk. Tujuannya untuk menjadikan berhasil pengindukan matang gonad bermutu bagi aktivitas pembibitan. Maka aktivitas pengembangbiakan serta membesarkan mempunyai peluang pemasaran yang lebih luas. Perhitungan $B / C$ ratio terkait pembenihan ikan lele secara alami diperoleh hasil 1,1 sehingga pembenihan ikan lele secara alami layak untuk dilanjutkan.

\section{Perhitungan Biaya Pembenihan Lele Sangkuriang secara Buatan}

Pembenihan lele sangkuriang secara buatan melalui proses penyuntikan, hal ini dilakukan dengan cara merangsang induk lele agar mau memijah melalui penyutikan zat berupa kelenjar hyphofisa (Khairuman dan Amri, 2008). Berikut rangkaian kegiatan pembenihan ikan lele dengan cara buatan dijelaskan dalam tabel berikut:

Tabel 3. Kegiatan pembenihan ikan lele secara buatan selama 1 siklus

\begin{tabular}{|l|l|l|l|}
\hline No & \multicolumn{1}{|c|}{ Kegiatan } & Hari ke- & Durasi \\
\hline 1 & Pembersihan tempat pembiakan & 1 & \\
\hline 2 & Pengeringan wadah pembiakan & 1 & \\
\hline 3 & Pemberian air & 2 & \\
\hline 4 & Penyediaan ijuk pembiakan & 2 & \\
\hline 5 & Penyeleksian induk & 2 & \\
\hline 6 & Penyuntikan induk & 2 & \\
\hline 7 & Melakukan stiping induk betina & 3 & \\
\hline 8 & Pengambilan sperma jantan & 3 & \\
\hline 9 & Pencampuran telur dan sperma & 3 & \\
\hline 10 & Penetasan telur & $3-4$ & 1 \\
\hline 11 & Cadangan makanan ikan & $4-6$ & 3 \\
\hline
\end{tabular}




\begin{tabular}{|c|l|l|l|}
\hline No & \multicolumn{1}{|c|}{ Kegiatan } & Hari ke- & \multicolumn{1}{|c|}{ Durasi } \\
\hline 12 & Pakan kutu air & $7-10$ & 4 \\
\hline 13 & Pakan cacing sutra & $11-15$ & 5 \\
\hline 14 & Pakan pellet halus & $16-30$ & 15 \\
\hline 15 & Pemanenan benih & 30 & \\
\hline
\end{tabular}

Sumber data: Data Primer, 2020

Tabel 4. Biaya operasional dalam 1 siklus di jelaskan pada tabel berikut.

\begin{tabular}{|l|l|l|r|r|}
\hline No & \multicolumn{1}{|c|}{ Kebutuhan } & Jumlah & Biaya Satuan (Rp) & Biaya Total (Rp) \\
& Biaya Tidak Tetap & & & \\
\hline 1 & Ovaprim & 8 buah & 75.000 & 600.000 \\
\hline 2 & Aquabides & 1 buah & 20.000 & 20.000 \\
\hline 3 & Jarum suntik & 1 buah & 15.000 & 2000 \\
\hline 4 & Tisu & 1 pak & 5000 & 15.000 \\
\hline 5 & ljuk pemijahan & 4 bungkus & 12.000 & 20.000 \\
\hline 6 & Reparasi kolam & 4 kolam & 10.000 & 48.000 \\
\hline 7 & Kutu air & 16 kaleng & 10.000 & 160.000 \\
\hline 8 & Cacing sutra & 60 kaleng & 100.000 & 100.000 \\
\hline 9 & Biaya listrik & 1 siklus & 10.000 & 20.000 \\
\hline 10 & Transportasi & 2 liter & 2500 & 10.000 \\
\hline 11 & Spon kawat & 4 buah & 30.000 & 60.000 \\
\hline 12 & Bak sortir & 2 buah & 180.000 & 180.000 \\
\hline 13 & Pellet halus & 1 sak & & 20.000 \\
\hline 14 & Lain-lain & & & 1.330 .000 \\
\hline & Total & & & 65.000 \\
\hline & Biaya Tetap & & 13.000 & 12.000 \\
\hline 1 & Selang & 5 meter & 12.000 & 150.000 \\
\hline 2 & Thermometer & 1 unit & 150.000 & 450.000 \\
\hline 3 & Aerator & 1 unit & & 677.000 \\
\hline 4 & Pompa air & 1 paket & & \\
\hline & Total & & & \\
\hline
\end{tabular}

Sumber data: Data Primer, 2020

Perhitungan $\mathrm{B} / \mathrm{C}$ ratio untuk pembenihan ikan lele dilakukan menggunakan sistem buatan diperoleh hasil 1,4 , hal ini diartikan bahwa usaha budidaya ikan lele secara buatan layak untuk di lanjutkan.

\section{KESIMPULAN DAN SARAN}

\section{KESIMPULAN}

Hasil data penelitian bahwa pembenihan ikan lele dilakukan menggunakan 2 sistem yakni pemijahan secara alami dan pemijahan secara buatan. Masing-masing besarnya biaya pendapatan dalam satu siklus pemijahan sebesar Rp 2.000.000,- / siklus untuk 
pembenihan secara alami. Sedangkan untuk biaya pendapatan untuk sistem pembenihan secara buatan sebesar Rp 3.000.000,- / siklus.

Penelitian terkait kelayakan usaha dari pembenihan secara alami di peroleh $B / C$ ratio sebesar 1,1 , selain itu untuk pembenihan secara buatan diperoleh $B / C$ ratio sebesar 1,4. Hal tersebut diartikan bahwa kedua sistem pembenihan ikan lele layak untuk dilanjutkan.

\section{S A R A N:}

Perawatan larva masa pengembangbiakan awal diperlukan perlengkapan awal baskom maupun kolam perawatan yang lebih baik. Hal ini dilakukan untuk menjauhkan diri dari kepadatan penebaran yang terlalu banyak serta tersebarnya penyakit yang mengakibatkan rendah tingkat keberlangsungan hidup bibit.

\section{DAFTAR PUSTAKA}

Anggriani, R, Iskandar, dan A. Taufiqurohman. 2012. Efektifitas Penambahan Bacillus sp. Hasil Isolasi dari Pencernaan Ikan Patin pada Pakan Komersial terhadap Kelangsungan Hidup dan Pertumbuhan Benih Ikan Nila Merah (Oreochromis niloticus). Jurnal Perikanan dan Kelautan 3 (3): 75-83

Khairuman dan Amri,K,. 2008. Buku Pintar Budidaya 15 Ikan Konsumsi. Agro Media Pustaka: Jakarta

Sundary, B. 2014. Penerapan Program Linier dalam Optimasi Biaya Pakan Ikan dengan Metode Simpleks (Studi Kasus PT. Indojaya Agrinusa Medan). Informasi dan teknologi IImiah (INTI). 156-161

Sumardika, P. 2013. Kewirausahaan Perikanan. Bina Sumberdaya MIPA: Jakarta Selatan

Wardhani, L. K,. M. Safrizal dan Chairi, A. 2011. Optimasi Komposisi Bahan Pakaian Ikan Tawar Menggunakan Metode Multi-Objektif, Seminar Nasional Aplikasi Teknologi Informasi 1-6 